\title{
Brain-Derived Neurotrophic Factor Is Required for the Maintenance of Cortical Dendrites
}

\author{
Jessica A. Gorski, Steven R. Zeiler, Susan Tamowski, and Kevin R. Jones \\ Department of Molecular, Cellular, and Developmental Biology, University of Colorado, Boulder, Colorado 80309
}

\begin{abstract}
Brain-derived neurotrophic factor (BDNF) is thought to be involved in neuronal survival, migration, morphological and biochemical differentiation, and modulation of synaptic function in the CNS. In the rodent cortex, postnatal BDNF expression is initially low but subsequently increases to reach maximal levels around weaning. Thus, BDNF expression peaks at a time when both structural and functional maturation of cortical circuitry occurs. Although the function of BDNF has been probed using many approaches, its requirements during this phase of life have not previously been examined genetically. To test the in vivo requirements for BDNF during this important phase of development we generated early-onset forebrain-specific BDNF mutant mice. Although these mice undergo forebrain-restricted deletion of $B D N F$ by Cre-mediated recombination during embryogenesis, they are healthy, and we did not detect the loss of specific cortical excitatory or inhibitory neurons. However, the neocortex of 5-week-old mice was thinner, attributable at least partly to neuronal shrinkage. Importantly, although visual cortical layer $2 / 3$ neurons in the mutants initially developed normal dendrite structure, dendritic retraction became apparent by 3 weeks of age. Thus, our observations suggest that cortically expressed BDNF functions to support the maintenance of cortical neuron size and dendrite structure rather than the initial development of these features. This is consistent with a role for BDNF in stabilizing the "survival" of circuitry during the phase of activity-dependent reorganization of cortical connectivity.
\end{abstract}

Key words: BDNF; dendrite; cortex; morphology; Cre-lox; neurotrophin; mouse; mutant

\section{Introduction}

BDNF, a secreted neurotrophin, regulates aspects of neuronal survival, migration, morphological and biochemical differentiation, and synaptic function (Bibel and Barde, 2000; Huang and Reichardt, 2001). Binding of BDNF to the receptor tyrosine kinase TrkB activates signal transduction pathways known to influence neuronal proliferation, survival, and differentiation (Miller and Kaplan, 2001). TrkB is also activated by neurotrophin (NT)-3 and NT-4/5 (Barbacid, 1994; Patapoutian and Reichardt, 2001). Both BDNF and TrkB are widely expressed in neocortical neurons. BDNF is expressed at low levels in the rodent cortex during prenatal development, expression rises dramatically during the postnatal period, and BDNF is the most abundant neurotrophin in both the adult rodent and human cortex (Maisonpierre et al., 1990; Timmusk et al., 1994; Webster et al., 2002). The striking and necessary actions of neurotrophic factors in promoting the survival and differentiation of peripheral nervous system

Received March 25, 2003; revised June 3, 2003; accepted June 6, 2003.

This work was supported by a Burroughs-Wellcome New Investigator in Pharmacology Award and grants from the American Cancer Society, the Colorado Council for Research and Creative Work, and Muscular Dystrophy Association (K.R.J.). We thank Chris Bassett, Tom Fuller-Rowel, Decha Sermwittawayong, Morgan Skurky-Thomas, and Tiffany Talley for technical support; Dr. Susan Dymecki for the FLP mouse strain; Anirvan Ghosh and Louis Reichardt for helpful suggestions; Jessica Hanover, Naomi Ruff, and Michael Stryker for their assistance with the biocytin injection procedures; Drs. Greg Lemke, Cindy Yee, Tom Finger, and Thomas Jessell for providing anti-SCIP, - $\beta$ galactosidase, and -ER81 antibodies; and Wen-Biao Gan for providing information before publication.

Correspondence should be addressed to Dr. Kevin R. Jones, 347 UCB, Department of Molecular, Cellular, and Developmental Biology, University of Colorado, Boulder, C0 80309. E-mail: krjones@stripe.colorado.edu. Copyright $\odot 2003$ Society for Neuroscience $\quad$ 0270-6474/03/236856-10\$15.00/0 neurons have driven intensive studies of the functions of BDNF and TrkB signaling in the cortex.

In vitro studies have demonstrated that BDNF has survivalpromoting activity on cortical neurons through a calciumdependent mechanism (Finkbeiner, 2000) and potent enhancement of inhibitory interneuron differentiation (Marty et al., 1997). In addition, BDNF and TrkB signaling can influence cortical dendrite growth. In cultured slice preparations, BDNF caused enhanced arborization of layer II/III and IV neurons (Horch et al., 1999; Niblock et al., 2000), but a loss of dendritic complexity in layer VI (McAllister et al., 1995). In addition to these influences on the survival and differentiation of cortical neurons, BDNF and TrkB signaling are known to modulate synaptic strength, and BDNF expression and secretion is regulated by neural activity, suggesting possible functions in the plasticity and homeostasis of cortical circuitry (Poo, 2001).

Studies of null BDNF and TrkB mutant mice have suggested relatively subtle $\mathrm{BDNF}$ requirements in the survival of most cortical neurons, but have indicated functions in the migration and differentiation these cells (Klein et al., 1993; Ernfors et al., 1994; Jones et al., 1994; Alcantara et al., 1997; Silos-Santiago et al., 1997; Gates et al., 2000; Polleux et al., 2002). However, interpretation of the phenotype of these null mutants during the postnatal period is complicated by their poor health. Circumventing these difficulties, analysis of late-onset ( $\sim 3-4$ weeks of age) forebrainrestricted $\operatorname{Trk} B$ mutant mice suggested that some cortical excitatory neurons are lost after dendritic retraction over a period of several weeks (Xu et al., 2000). In addition, profound deficits in 
spatial learning were documented by Minichiello et al. (1999) using a different late-onset $\operatorname{TrkB}$ mutant.

Although analysis of prenatal BDNF requirements is feasible using null mutant mice, and later adult requirements for BDNF have been indirectly probed using late-onset $\operatorname{Trk} B$ mutants, the initial genetic requirements of the BDNF-TrkB signaling system in the cortex during the period when BDNF expression rises dramatically have not been examined. To test these requirements specifically, we generated early-onset forebrain-restricted BDNF mutant mice. Notably, we were unable to detect specific cortical neuron losses, and layer II/III pyramidal neurons initially developed normal soma size and basal dendritic tree complexity. However, these cells subsequently shrank in size and lost dendritic complexity at $\sim 3$ weeks of age, when BDNF expression normally rises dramatically in the cortex, indicating that the onset of BDNF expression is necessary for the maintenance of dendritic structure.

\section{Materials and Methods}

Generation of the BDNF ${ }^{\text {lox }}$ targeting construct. The $5^{\prime}$ lox site was inserted into a DraIII site in the $5^{\prime}$ untranslated region (UTR), 14 bp downstream of the exon $\mathrm{V}$ splice acceptor site and 18 bp upstream of the initiation codon (Hohn et al., 1990). The 3' lox site was inserted into a BssHII site in the $3^{\prime}$ UTR $1 \mathrm{~kb} \mathrm{3'}$ of the stop codon, downstream of the first of the two polyadenylation signals (Timmusk et al., 1993). A Simian Virus 40 (SV40)-polyadenylation trimer (Maxwell et al., 1989) was inserted upstream of the lox site and an Escherichia coli lacZ gene was inserted immediately $3^{\prime}$ to the lox site, followed by Flp recombinase target (FRT)flanked phosphoglycerate phosphoglycarate kinase (PGK) neomycin cassette (Gorski et al., 2002). The resulting genomic sequence containing the $5^{\prime}$ lox site, beginning with the DraIII site and ending with the DraIII 3 ' half-site was: CACCAGGTGATAACTTCGTATAGCATACATTATACGAAGTTATATAACCAGGTG. The $3^{\prime}$ lox site, ending with the start codon of the lac $Z$ gene: ATAACTTCGTATAGCATACATTATACGAAGTTATCCGCCACCATG.

Isolation of mouse strain. The linearized targeting construct was electroporated into D3 embryonic stem cells (Doetschman et al., 1985) and screened for homologous recombinants using the polymerase chain reaction. The primers used were P1: ACACACACTTGAGAAGGGGG (MBDSA9) and P2: CTCTTCTCACCTGGTTATATAACTTCT (Fig. $1 A)$. Targeted clones were identified and expanded and the genomic structure of the mutated BDNF gene was confirmed by DNA blot analysis. DNA for both PCR and DNA blot analysis was prepared as described previously (Laird et al., 1991). Correctly targeted clones were injected into blastocysts, and mice carrying the mutation were derived using standard methods.

Genetics and genotyping. All animal procedures were conducted in accord with U.S. Public Health Service guidelines and with the approval of the University of Colorado Institutional Animal Care and Use Committee. Two BDNF ${ }^{\text {lox }}$ strains were isolated from independent embryonic stem cell clones, and the structure of the targeted locus was confirmed by DNA blot analysis (Fig. 1B). To eliminate the PGK-neomycin selectable marker, $B D N F^{\text {lox }}$ mice were mated to the FLP-4917 Flp recombinaseexpressing transgenic strain (Dymecki, 1996). Anatomical analyses were performed on mice backcrossed to C57BL/6J for 3-10 generations from litters culled between postnatal day 7 (P7) and P14 to five or fewer pups.

$B D N F$ protein ELISA. BDNF protein was quantitated using the BDNF $\mathrm{E}_{\max }$ ImmunoAssay System (Promega, Madison, WI). Tissue was dissected and weighed and protein was extracted and quantitated following the manufacturer's protocol, except for a change in lysis buffer (to $50 \mathrm{~mm}$ Tris- $\mathrm{HCl}, 0.6 \mathrm{M} \mathrm{NaCl}, 0.2 \%$ Triton X-100, 1\% BSA, $0.1 \mathrm{~m}$ benzothonion chloride, 1 mm benzamidine, $0.1 \mathrm{~mm}$ PMSF, pH 7.4). All samples from an individual animal were run in triplicate, and the resulting quantities were averaged.

Determination of cortical layer thickness. Mice were heavily sedated by the intraperitoneal injection of $14 \mu \mathrm{l} / \mathrm{g}$ avertin ( $0.025 \mathrm{gm} \mathrm{2,2,2}$ tribromoethylalcohol, $0.025 \mathrm{ml}$ tertamyl alcohol in PBS) and transcardially per- fused with $4 \%$ paraformaldehyde in $0.1 \mathrm{~m}$ phosphate buffer, $\mathrm{pH}$ 7.4. The brains were either cryoprotected overnight in $22 \%$ sucrose in 0.1 M phosphate buffer and sectioned coronally at $40 \mu \mathrm{m}$ on a cryostat (Leica, Nussloch, Germany) or postfixed for over $12 \mathrm{hr}$ and sectioned at $50 \mu \mathrm{m}$ with a vibrating microtome (Leica). Sections were collected into PBS, washed in $0.5 \mathrm{~m}$ Tris, pH 7.5, mounted on slides (Superfrost; Fisher Scientific, Pittsburgh, PA), and counterstained with cresyl violet, $(0.2 \%$ cresyl violet, $0.5 \%$ acetic acid, $0.01 \mathrm{~m}$ sodium acetate, and $0.02 \mathrm{M}$ sodium hydroxide) and coverslipped with Permount (Fisher Scientific). Primary somatosensory and visual cortices [identified as per Franklin and Paxinos (1997) and Antonini et al. (1999)] were identified at six positions, $100 \mu \mathrm{m}$ apart, along the rostrocaudal axis. Layer boundaries were traced using a camera lucida drawing tube, the thicknesses of layers II-VI measured at three locations along the medial-lateral axis on each section, and these values were averaged. There were no significant differences in the values obtained for the more rostral sections compared with the more caudal sections within an animal ( $p>0.05, t$ test), so data from all six sections per animal were averaged, giving a mean layer thickness for somatosensory or visual cortex in that animal. One-way ANOVA with a Tukey post hoc test was used to determine statistical significance between genotypes.

Neuron counts and density determination. Alternating 50 and $500 \mu \mathrm{m}$ vibratome sections were prepared as above. A block $\sim 2 \mathrm{~mm}$ by $2 \mathrm{~mm}$ of the primary visual cortex was dissected from the $500 \mu \mathrm{m}$ sections, embedded in JB4 plastic resin (Electron Microscopy Sciences, Fort Washington, PA), and sectioned coronally at $3 \mu \mathrm{m}$ with a glass knife. Sections were collected into water, mounted, and counterstained with cresyl violet. Layers were identified, outlined, and measured in the $50 \mu \mathrm{m}$ cresyl violet-stained sections of primary visual cortex. Although the overall thickness of the cortex varied across the set of $500 \mu \mathrm{m}$ sections from an animal, the fractional layer contributions did not vary significantly. Thus, cortical layer boundaries were defined as percentages of total cortex thickness, which were used to draw layer boundaries onto the $3 \mu \mathrm{m}$ sections. Neurons (cells with a darkly stained cytoplasm and a large, distinct, and more lightly stained nucleus with a nucleolus) were counted in a $215 \mu \mathrm{m}$ wide strip of cortex from pictures taken at $630 \times$ magnification, cortical area was measured using software (Openlab, Coventry, England), and the density of neurons was calculated. One-way ANOVA with a Tukey post hoc test was used to determine statistical significance.

Diolistics. Diolistics was performed as described in Gan et al. (2000) with slight modification. The lipophilic dyes DiI and DiO (Molecular Probes, Eugene, OR) were dissolved in methylene chloride to a final concentration of $0.06 \mathrm{mg} / \mu \mathrm{l}$ in $50 \mu \mathrm{l}$. The solubilized dyes and $25 \mathrm{mg}$ of tungsten beads were sonicated in a water bath sonicator to dryness, then $1.5 \mathrm{ml}$ of water was added and the beads were sonicated for $5 \mathrm{~min}$. Approximately $75 \mathrm{~cm}$ of Gold Coat tubing (Bio-Rad, Hercules, CA) was coated with $3 \mathrm{ml}$ of DiI/DiO tungsten slurry. Coronal sections $(200 \mu \mathrm{m})$ were prepared as described above on a vibrating microtome. Eight to 12 visual cortical slices were shot using this tubing in a gene gun (Bio-Rad) at $70-80 \mathrm{psi}$, through a $3 \mu \mathrm{m}$ pore size and $8.0 \times 10^{5}$ pores $/ \mathrm{cm}^{2}$ density filter (Falcon cell culture inserts, catalog number 3096; Becton Dickinson, Mountain View, CA). The slices were then placed in PBS, incubated in the dark at room temperature overnight, then at $4^{\circ} \mathrm{C}$ overnight in $4 \%$ paraformaldehyde in $0.1 \mathrm{~m}$ sodium phosphate, $\mathrm{pH} 7.4$, washed in $100 \mathrm{~mm}$ Tris, pH 7.4 and mounted onto Superfrost/Plus microscope slides (Fisher Scientific) using ProLong Antifade mounting media (Molecular Probes). Fluorescence images (1000× magnification) were taken at 0.5 $\mu \mathrm{m}$ intervals through the entire visible extent of each cell analyzed using a Zeiss (Oberkochen, Germany) Axioplan deconvolution microscope with attached Hamamatsu (Bridgewater, NJ) C4742-95 digital camera. The number of primary dendrites, branches per primary dendrites, and soma area were analyzed with the investigator unaware of the genotype using the Open Lab software suite (Improvision, Coventry, UK).

Biocytin analysis of dendritic complexity. Layer II/III neurons were retrogradely filled as described previously (Xu et al., 2000). Vibratome sections $(75 \mu \mathrm{m})$ were processed for peroxidase staining. Endogenous peroxidases were quenched by $30 \mathrm{~min}$ incubation in 10\% methanol and $3 \%$ $\mathrm{H}_{2} \mathrm{O}_{2}$ in PBS. Sections were then rinsed five times in PBS and incubated for $2-5 \mathrm{hr}$ in $0.4 \%$ vectastain solution A and B (Vector Laboratories, 

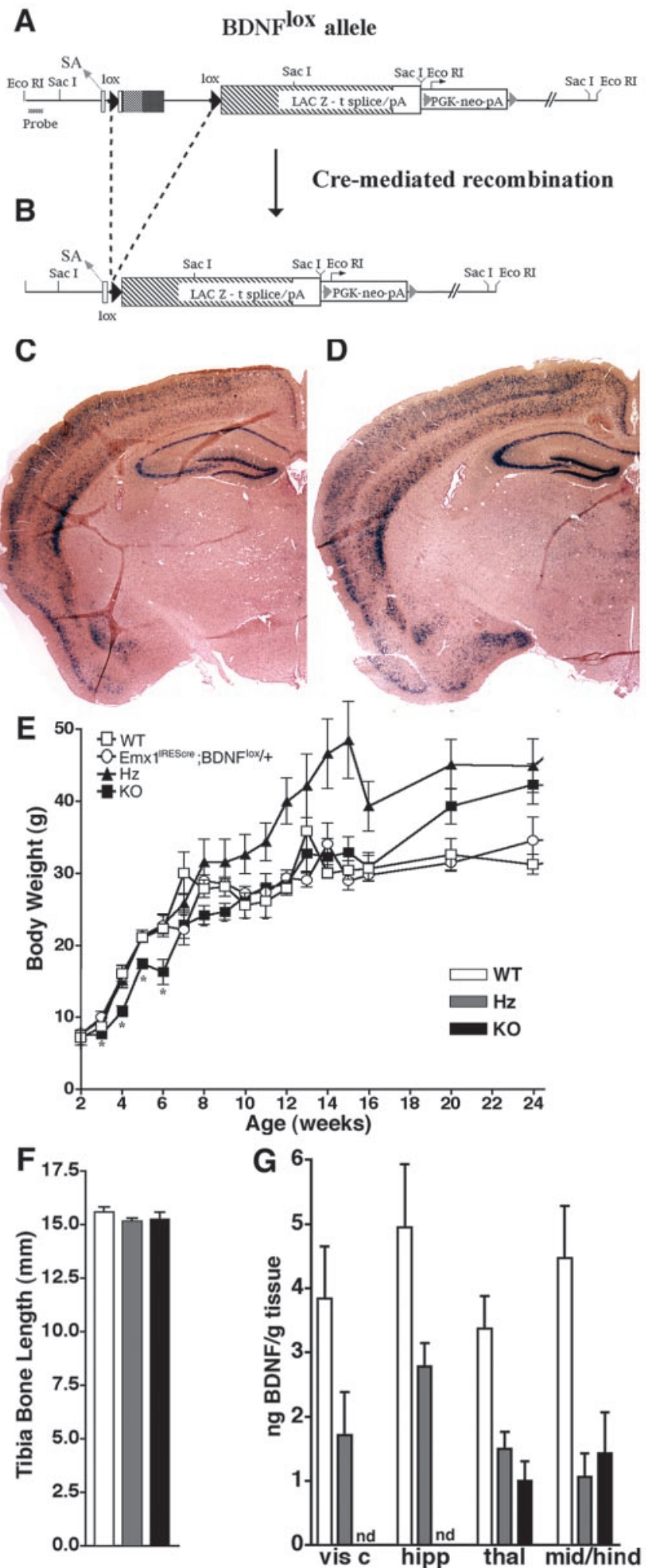

Figure 1. Generation of forebrain-restricted BDNF mutant mice. $A$, Diagram of the BDNF lox allele. Exon V, the BDNF coding exon, is shown schematically at the top [open bar, 5' -UTR; shaded bar, pro region (a portion of the BDNF procursor protein removed by proteolytic processing); filled bar, mature hormone region], flanked by lox sites (filled triangles), and followed by lacZ (hatched bar), an SV40 intron-polyA (open bar), and an FRT-flanked PGK neomycin (open bar with triangles). Location of the splice acceptor $(S A)$ is denoted by an arrow. B, Diagram of the $B D N F^{\text {lox }}$ allele after Cre-mediated recombination. BDNF-coding sequences in exon $V$ are excised and lac $Z$ is brought downstream of the splice acceptor site and under control of BDNF promoters. C, X-gal stained $10 \mu \mathrm{m}$ coronal section through Emx $1^{\text {IREScre }} ;$ BDNF $^{\text {lox/+ }}$ brain. D, X-gal stained
Burlingame, CA) and $0.0075 \%$ Triton X-100 in PBS, rinsed three times in PBS, incubated for $5 \mathrm{~min}$. in $0.1 \%$ glutaraldehyde in PBS, then rinsed three times in PBS and allowed to develop for $2-5 \mathrm{~min}$. in $0.014 \%$ cobalt chloride, $0.014 \%$ nickel chloride, and $0.003 \% \mathrm{H}_{2} \mathrm{O}_{2} 0.05 \%$ diaminobenzidine in PBS. Sections were mounted on slides, dehydrated, and coverslipped as described above.

Cells were reconstructed and drawn using a camera lucida drawing tube at $400 \times$ magnification, and a modified Sholl analysis (Sholl, 1953) was used. Concentric circles in $20 \mu \mathrm{m}$ diameter increments were drawn around the center of the reconstructed soma, and the number of dendrites crossing each circle was counted. In addition, the number of primary, secondary, tertiary, and higher-order dendrites, dendrite branch points and end points were counted. Soma sizes were measured using NIH Image software. One-way ANOVA with a Tukey post hoc test was used to determine statistical significance.

Cell counts using immunocytochemical markers. Cryostat $(40 \mu \mathrm{m})$ or vibratome $(50 \mu \mathrm{m})$ sections, prepared as described above, were collected into PBS, incubated in block (Tris-buffered saline, $0.4 \%$ Triton X-100, $1 \%$ glycine, $1 \%$ bovine serum albumin, and $1 \%$ normal goat serum) for $4 \mathrm{hr}$ at room temperature, and then incubated in primary antibody for $2 \mathrm{~d}$ at $4^{\circ} \mathrm{C}$. Primary antibodies specific for $\beta$-galactosidase $(1: 1000$, ICN Pharmaceuticals, Auroria, OH; or 1:2000, from C. Yee and T. Finger, University of Colorado Health Sciences Center, Denver, CO), NeuN (1:1000, Molecular Probes), Calretinin (1:1000), Calbindin (1:200), GABA (1:500, Sigma, St Louis, MO), NPY (1:1000, Incstar, Minneapolis, MN), S100 (1:500, DAKO, Glostrup, Denmark), SCIP (1:100, a gift from Dr. G. Lemke, Salk Institute, San Diego, CA) and ER81 (1:500, a kind gift from Dr. T. M. Jessell, Columbia University, New York, NY).

Sections were washed three times in TBST (Tris-buffered saline, $0.4 \%$ Triton X-100) for 5 min and incubated in Alexa 488 goat anti-mouse IgG antibody (1:200, Molecular Probes) and Alexa 546 goat anti-rabbit IgG antibody (1:200, Molecular Probes) for $2 \mathrm{hr}$ at room temperature. Sections were washed twice in TBST, once in TBS and once in $0.5 \mathrm{M}$ Tris, $\mathrm{pH}$ 7.5 , before mounting on Superfrost slides and coverslipped with Fluoromount (Fisher Scientific), or they were incubated in $0.2 \mathrm{M} \mathrm{KCl}, \mathrm{pH} 2$, for $2 \mathrm{~min}$, incubated in $0.0001 \%$ Bisbenzamide in $0.2 \mathrm{M} \mathrm{KCl}, \mathrm{pH} 2$, for $45 \mathrm{sec}$, washed in $0.2 \mathrm{M} \mathrm{KCl}, \mathrm{pH} 2$, for $2 \mathrm{~min}$ and then rinsed in $0.5 \mathrm{M}$ Tris, $\mathrm{pH} 7.5$, before coverslipping as above. Images were captured using a microscope (Leica) running Openlab software (Improvision).

Calbindin- and parvalbumin-positive cells were counted in three strips of primary visual cortex $1200 \mu \mathrm{m}$ wide at $100 \times$ magnification. Immunopositive cells were counted across the entire thickness of the cortex, except for Calbindin, for which only layers IV-VI were counted because Calbindin is also expressed in pyramidal neurons in layers II/III. Between five and eight strips per animal of primary visual cortex $335 \mu \mathrm{m}$ wide, at $100 \times$ magnification, were used to count the ratio of GABA, SCIP, and ER81-positive cells to NeuN-positive cells. Counts were performed blind to the animal's genotype. One-way ANOVA with a Tukey post hoc test was used to determine statistical significance.

\section{Results}

Generation of early forebrain-restricted BDNF mutant mice To enable the generation of tissue-specific BDNF mutant mice using the Cre-site-specific DNA recombinase, lox sites were inserted into exon $\mathrm{V}$, the BDNF protein-coding exon. A trimerized polyadenylation signal was inserted upstream of the $3^{\prime}$ lox site, and an E. coli lacZ gene was inserted downstream (Fig. $1 A$ ). Cre-

$\leftarrow$

$10 \mu \mathrm{m}$ coronal section through BDNF ${ }^{\text {IacZ/+ }}$ brain. E, Growth of wild-type (WT), Emx $1^{\text {IREScre, }}$ $B D N F^{\text {lox } /+}, B D N F^{n e o /+}$ heterozygous (Hz), and Emx-BDNF ${ }^{K O}$ mice (KO). Emx-BDNF $F^{K O}$ mice weigh significantly less at $3,4,5$, and 6 weeks of age. ${ }^{*} p<0.05$. F, Tibia bone length measured for 5 -week-old mice ( $n>10$ mice per genotype). No significant differences were detected between genotypes. G, BDNF protein quantitated by ELLSA, expressed as nanograms of BDNF protein per gram of wet tissue, in extracts of brain structures from 5 -week-old mice ( $n=3$ mice per genotype). BDNF was not detected (nd) in the visual cortex and hippocampus of Emx-BDNF ${ }^{K O}$ mice. vis c, Visual cortex; hipp, hippocampus; thal, thalamus; mid/hind, midbrain/hindbrain. 
mediated recombination deletes the polyadenylation signals, allowing lacZ transcription and translation in place of BDNF (Fig. $1 B)$. Mice homozygous for $B D N F^{l o x}\left(B D N F^{l o x} / l o x\right)$ are viable and fertile, and in 5-week-old $B D N F^{\text {lox/lox }}$ mice BDNF protein concentration in visual cortex and hippocampus was not significantly different from wild-type ( $n=4$ mice/genotype, $p>0.05)$.

To produce forebrain-restricted $B D N F$ mutant mice, $B D N F^{\text {lox } /+}$ mice were mated to Emx $1^{\text {IREScre/+ }} ; \mathrm{BDNF}^{\text {neo/+ }}$ mice. $E m \times 1^{\text {IREScre/+ }}$ mice, heterozygous for the Emx1 ${ }^{\text {IREScre }}$ allele, express Cre recombinase by embryonic day 10.5 in the precursors of cortical and hippocampal excitatory neurons and glia, causing recombination between lox sites, without expression in most subcortical structures and peripheral tissues (Gorski et al., 2002). Forebrain-specific mutant mice have the genotype $E m \times 1^{I R E S c r e /+}$; $B D N F^{\text {neo/lox }}$ (referred to hereafter as $E m x-B D N F^{K O}$ ). Control genotypes used included mice referred to as wild-type (including true wild-type, Emx $1^{\text {IREScre/+ }}$, and $B D N F^{\text {lox/+ }}$ genotypes) and heterozygotes (including $B D N F^{\text {neo/t+ }}$ and $B D N F^{\text {neo/lox }}$ ).

\section{Extent and specificity of the early forebrain-restricted BDNF mutation}

Although we previously characterized the timing, tissue, and celltype specificity of Emx1 $1^{I R E S c r e}$-mediated recombination using Cre-dependent reporter mouse strains (Gorski et al., 2002), we wanted to determine directly its activity on the $B D N F^{l o x}$ allele. Spatial and temporal specificity of recombination was characterized by X-gal staining of brains from $E m \times 1^{\text {IREScre/+ }} ; B D N F^{\text {lox/+ }}$ mice at 2, 3, and 5 weeks of age. Recombination was extensive in the neocortex, hippocampus, and amygdala and was scarce to undetectable in other CNS regions. The onset and extent of $\beta-\mathrm{Gal}$ expression in the neocortex and hippocampus of $E m \times 1^{I R E S c r e /+}$; $B D N F^{l o x /+}$ mice was both qualitatively (Fig. $1 C, D$ ) and quantitatively (data not shown) indistinguishable from age-matched $B D$ $\mathrm{NF}^{\text {lacZ/+ }}$ mice indicating that Emx $x^{I R E S c r e /+}$ causes essentially complete deletion of the BDNF coding sequences in neocortex and hippocampus before the onset of BDNF expression.

To further determine the efficacy of the Emx-BDNF ${ }^{K O}$ mutation, BDNF protein from the brains of 5-week-old mice was quantified. BDNF protein was undetectable in the visual cortex and hippocampus of $E m x-B D N F^{K O}$ mice (Fig. $\left.1 G\right)(n=3$ mice/ genotype, $p<0.001)$. Although BDNF protein in thalamus and midbrain/hindbrain structures of $E m x-B D N F^{K O}$ mice was reduced compared with wild-type mice ( $p<0.01$ ), only the cortex and hippocampus were significantly different compared with heterozygous mice $(p<0.05)$, indicating that the subcortical reductions are attributable mostly to the $E m x-B D N F^{K O}$ mice having one $B D N F^{\text {neo }}$ allele. Thus, these data document an effectively complete loss of BDNF in the cortex and hippocampus of $E m x-B D N F^{K O}$ mice, and reductions comparable to those found in heterozygotes in the thalamus and midbrain/hindbrain.

\section{General characteristics of $E m x-B D N F^{K O}$ mice}

$E m x-B D N F^{K O}$ mutant mice often opened their eyes $1 \mathrm{~d}$ later than their littermates, at P15 instead of P14, suggesting that they mature slightly more slowly than their littermates. At the ages of 3 and 5 weeks $E m x-B D N F^{K O}$ mice weighed less than their littermates (Fig. $1 E$ ). However, between 2 and 12 weeks, there was not a significant difference in tibia length between genotypes, indicating that skeletal growth was not affected, and by 8 weeks of age the body weights of wild-type and $E m x-B D N F^{K O}$ mutant mice were not significantly different (Fig. $1 F$ ). Beyond 16 weeks of age, $E m x-B D N F^{K O}$ mice developed mild obesity (35\% increase in body mass at 16 weeks compared with wild-type, $p<0.05, n=$
10). $B D N F^{\text {neo/+ }}$ mice developed more severe obesity and at a younger age, by 8 weeks $(80 \%$ increase in body mass at 8 weeks compared with wild-type, $p<0.05, n=10$ ) as reported previously (Lyons et al., 1999; Kernie et al., 2000). Interestingly, Emx $1^{\text {IREScre }}$; $B D N F^{\text {lox/+ }}$ mice did not become obese, indicating that, in contrast to widespread $B D N F$ heterozygosity, forebrainrestricted $B D N F$ heterozygosity is not sufficient to cause obesity.

Of eight mutants allowed to age, two died between 12 and 14 months, 5 between 14 and 16 months, and 1 at 18 months of age, suggesting a shortening of lifespan. $E m x-B D N F^{K O}$ mice exhibited poor fecundity; only two litters were born from 20 matings in which an $E m x-B D N F^{K O}$ male was paired with a wild-type female or vice versa (10 matings each way). $E m x-B D N F^{K O}$ males appeared more aggressive than normal and neither males nor females built normal nests. Detailed behavioral analysis of Emx$B D N F^{K O}$ mice has documented that although abnormalities were not detected in tests for ataxia and anxiety, there are substantial deficits in spatial and nonspatial learning (Gorski et al., 2003).

\section{Cortical volume is reduced but cell losses are not apparent} Despite the behavioral deficits exhibited by $E m x-B D N F^{K O}$ mice, initial examination of their brains revealed relatively normal $c y-$ toarchitecture. Given the evidence supporting a role for BDNF/ TrkB signaling in the survival, differentiation, and function of cortical neurons, we analyzed more carefully the cortical anatomy of $E m x-B D N F^{K O}$ mice. The cortex of 5-week-old Emx$B D N F^{K O}$ mice was thinner than in control mice (Fig. $2 A-F$ ). Somatosensory cortical thickness was reduced by $12 \%(p<$ $0.001, n=3$ ) and visual cortical thickness was reduced by $17 \%$ $(p<0.001, n=3)$. Determination of the absolute number of neurons in specific cortical regions is impractical, thus, we quantified neuronal density. A $22 \%$ increase in neuron density was found in layer II/III of Emx-BDNF ${ }^{K O}$ visual cortex compared with wild-type (Fig. $2 C)(p<0.01, n=3)$, suggesting that thinning of the cortex is attributable at least partly to shrinkage of neurons. Layers IV-VI showed a trend toward increased density that was not statistically significant (Fig. 2G).

Late-onset forebrain-restricted $\operatorname{Trk} B$ mutant mice were reported to lose some excitatory neurons in layer $\mathrm{V}$, between 6 and 10 weeks of age, several weeks after the loss of TrkB (Xu et al., 2000). The lost neurons included subsets of neurons expressing ER81, an ETS family transcription factor (Lin et al., 1998), and SCIP, a POU domain transcription factor (Monuki et al., 1989). We counted these cells in 5-week-old mice but found no significant difference in the ratio of ER81 $+/ \mathrm{NeuN}+$ or SCIP $+/ \mathrm{NeuN}+$ cells between $E m x-B D N F^{K O}$ mice and control genotypes (Fig. $3 A-F)$ ( $n=3$ mice per genotype). Thus, we did not detect a requirement for BDNF in the differentiation or survival of SCIP or ER81-expressing layer V excitatory neurons through 5 weeks of age.

To test whether cortically produced BDNF is involved in promoting the migration, chemical differentiation, and/or survival of cortical inhibitory interneurons, we examined the distribution of GABA-, calbindin-, parvalbumin-, neuropeptide Y (NPY)and calretinin-expressing cells in the somatosensory and visual cortices of 3- and 5-week-old mice. No differences in the qualitative pattern of immunostaining (Fig. $4 A$ ), or in the number of GABA-, calbindin-, or parvalbumin-expressing cells were detected between genotypes (Fig. $4 B, C$ ). Thus, as determined using these methods, BDNF was not required for the migration, proliferation, survival, and biochemical differentiation of most cortical inhibitory interneurons through 5 weeks of age.

The cortex is highly populated with astrocytes and oligoden- 

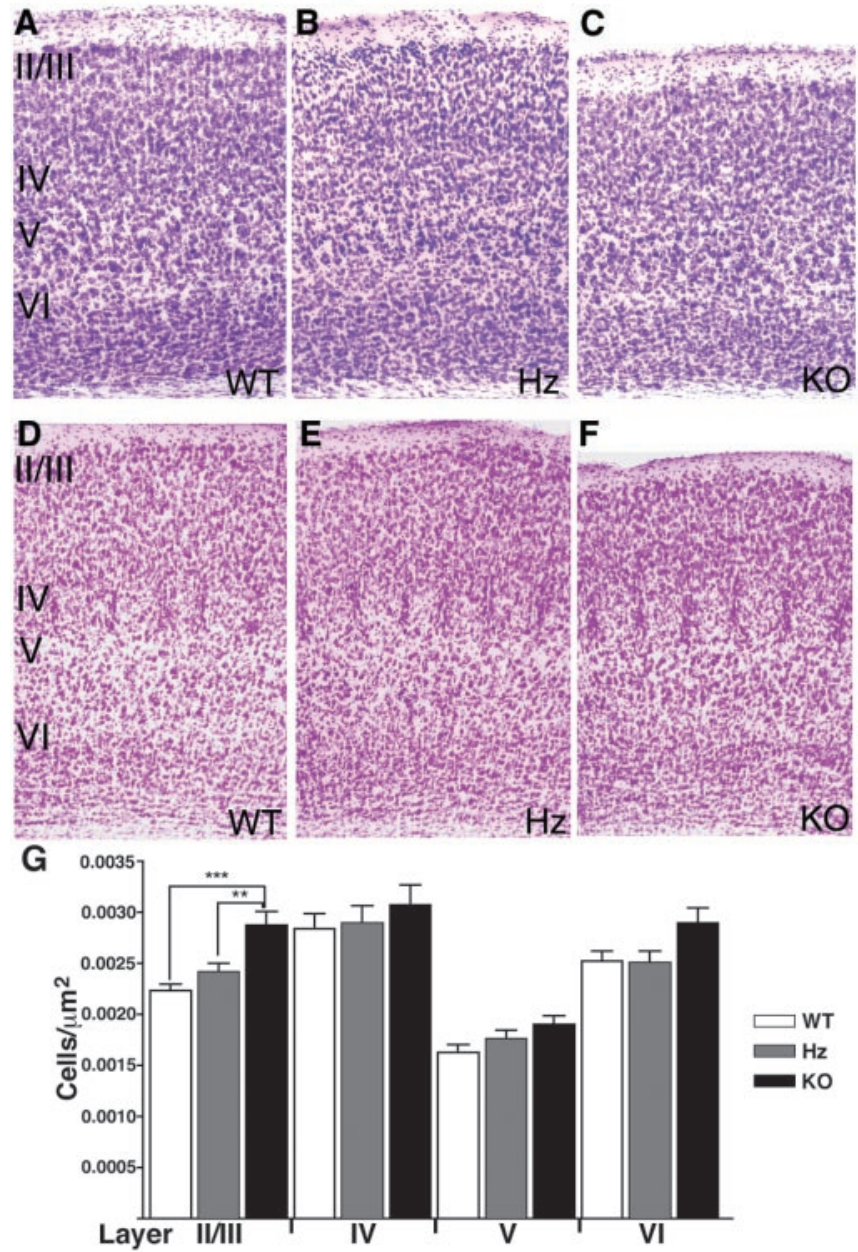

Figure 2. Cortical thinning in $E m x-B D N F^{K O}$ mice. (resyl violet-stained $50 \mu \mathrm{m}$ coronal sections of visual $(A-C)$ and somatosensory $(D-F)$ cortices from 5 -week-old WT, Hz, and KO mice. Cortical thickness is reduced in $\mathrm{KO}$ mice, but the cytoarchitecture appears generally normal and barrels are apparent in somatosensory cortex $(D-F)$. G, Neuronal density in visual cortex of 5 -week-old mice ( $n=3$ mice per genotype). Neurons are distributed more densely in layer II/III of K0 mice $(p<0.05)$.

drocytes, and these cells are known to express the truncated TrkB receptor (Frisen et al., 1993) as well as the full-length TrkB receptor after injury (McKeon et al., 1997), and they have been reported to respond to BDNF (Roback et al., 1995). To determine whether a disruption of the proportion of glia to neurons contributed to the cortical thinning, we counted non-neuronal cells in the visual and somatosensory cortex. There was no significant difference in the ratio of $4^{\prime}, 6^{\prime}$-diamidino-2-phenylindole-positive nuclei or S-100-positive astrocytes to NeuN-positive neurons (Fig. $3 G-I, K, L$ ), suggesting that $E m x-B D N F^{K O}$ mice have neither lost significant glial populations nor undergone extensive gliosis. Taken together, these data support the hypothesis that cortically produced BDNF is not required for survival of the majority of neurons or glia in the cortex to 5 weeks of age. The absence of detected cell losses and the observed increase in neuronal density suggested that shrinkage of cortical neurons could cause cortical thinning in $E m x-B D N F^{K O}$ mice.

$\mathrm{BDNF}$ is required for the maintenance of neuronal morphology

Reduced neuron soma size or reduced extent of dendritic arborization could contribute to cortical thinning. Because layer
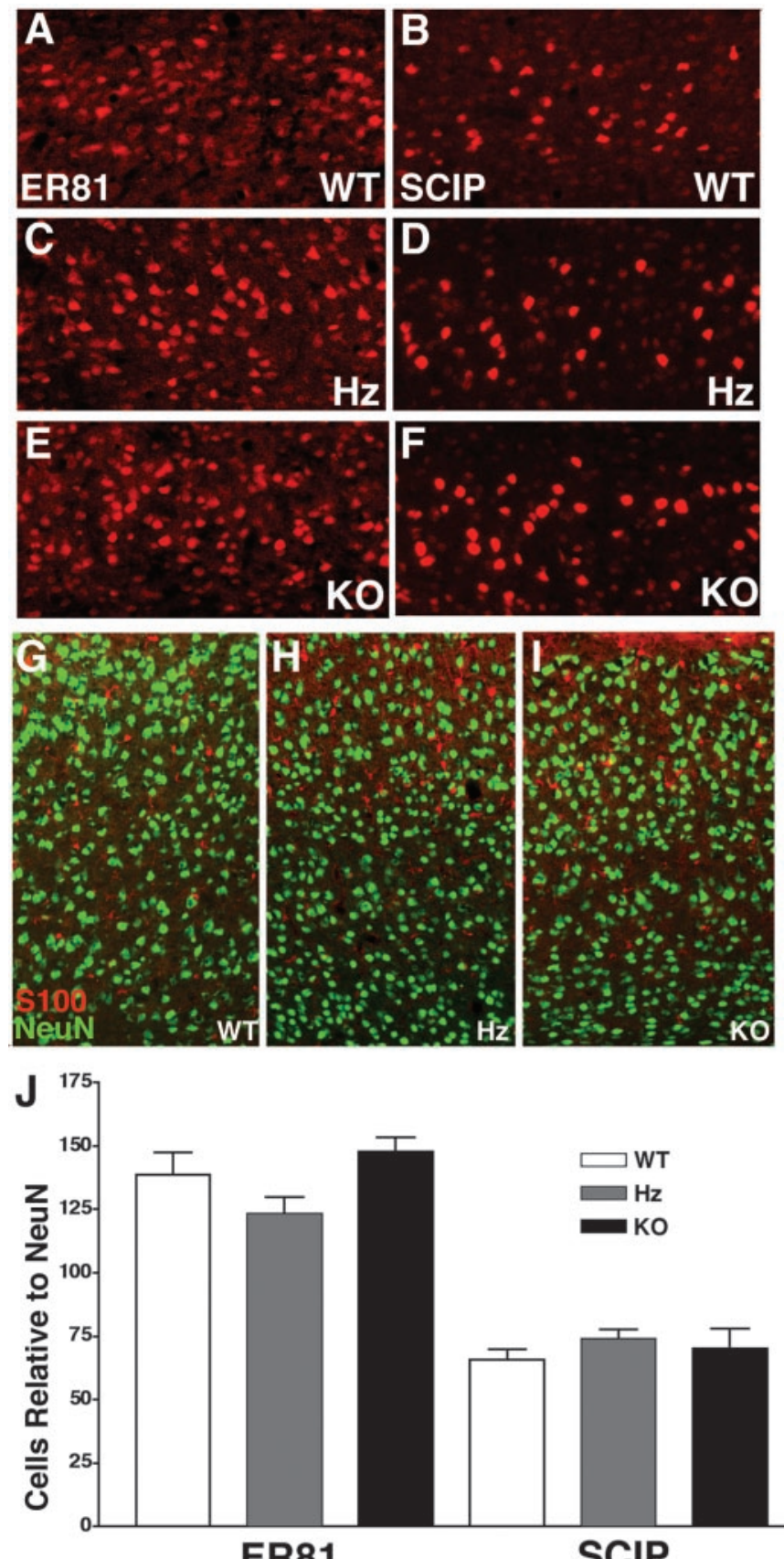

ER81
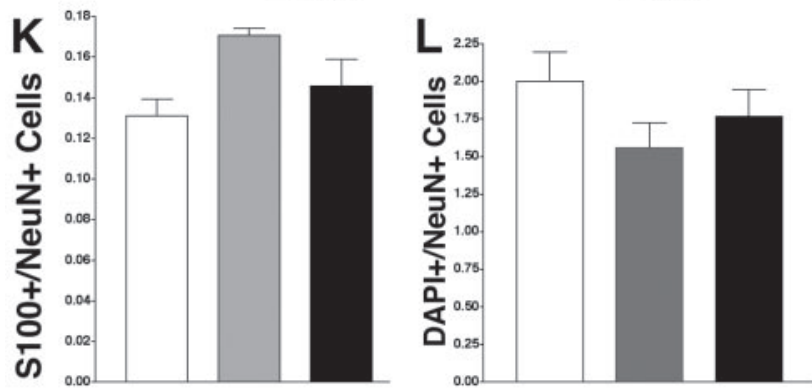

Figure 3. Absence of detectable neuronal or glial losses at 5 weeks of age. $A-F,(20 \mu \mathrm{m})$ of layer $V$ of primary visual cortex processed for $\operatorname{ER} 81(A, C, E)$ or $S C I P(B, D, F)$ immunocytochemistry. $G-I$, Coronal sections primary visual cortex sections $(10 \mu \mathrm{m})$ processed for $S 100$ and NeuN immunoreactivity. Quantitation of ER81 and SCIP-positive layer V neurons relative to NeuNpositive cells $(J)$, ratio of $S-100$-positive astrocytes to NeuN-positive neurons $(K)$, and the ratio of total cells to NeuN-labeled neurons $(L)$ revealed no differences between the genotypes ( $p>$ $0.05, n=3$ mice per genotype). 
A
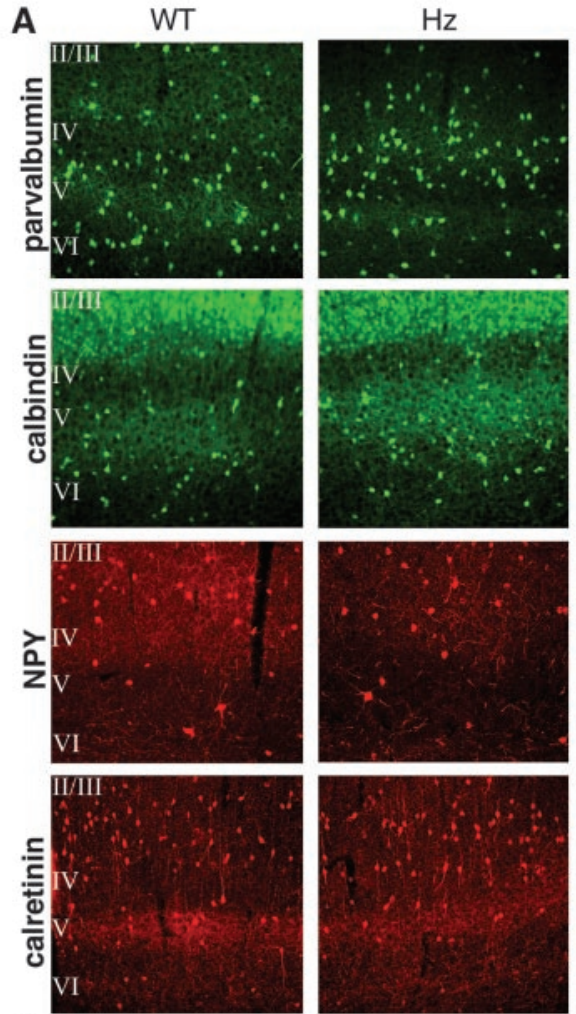

B
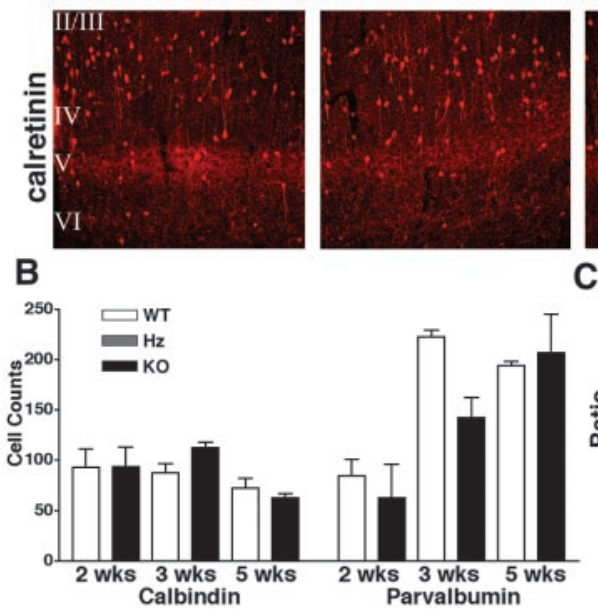

\section{corth}
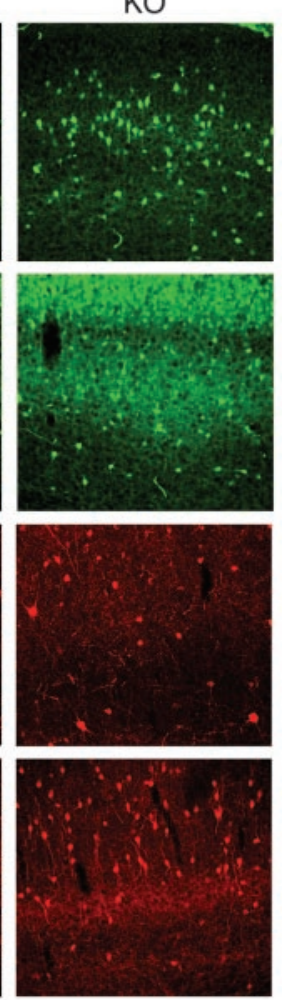

$\left.{ }^{0.15}\right]$

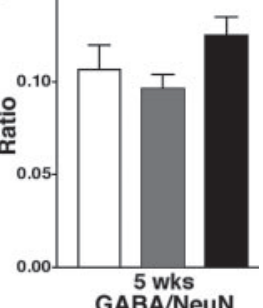

Figure 4. Apparently normal biochemical differentiation of cortical inhibitory neurons. $A$, Coronal sections $(40 \mu \mathrm{m})$ of primary visual cortex from 3-week-old mice processed for parvalbumin, calbindin, NPY, and calretinin immunoreactivity revealed no gross differences in expression pattern. $B$, Quantification of calbindin- and parvalbumin-positive neurons from primary visual cortex of 2-, 3-, and 5-week-old WT and KO mice revealed no differences between the genotypes ( $p>0.05, n=3$ mice per genotype). C, The ratio of $\mathrm{GABA}^{+} / \mathrm{NeuN}^{+}$neurons is not significantly different at 5 weeks of age ( $p>0.05, n=3$ mice per genotype).

II/III had significantly increased neuron density at 5 weeks of age (Fig. 2C), we studied layer II/III neurons. At 5 weeks of age, the soma area was reduced by 29 and $24 \%$ in $E m x-B D N F^{K O}$ mice compared with wild-type and heterozygotes, respectively $(p<$ $0.001)$. This result indicated that soma shrinkage contributed to cortical thinning, but did not discriminate between two possibilities; either a failure in the initial development of soma size or the development of normal soma size followed by contraction. To distinguish between these possibilities, we analyzed soma size at two younger ages. At 2 weeks of age the neuron soma area was not significantly different between the genotypes $(p>0.7)$ (Fig. 5A$C)$, but at 3 weeks of age there was a 28 and $22 \%$ decrease in soma area in $E m x-B D N F^{K O}$ mice compared with wild-type and heterozygous mice, respectively ( $p<0.001$ and $p<0.05$, respectively). Between 2 and 5 weeks of age, the soma size did not change significantly in the wild-type and heterozygous mice. Notably, the soma area shrank between 2 and 3 weeks of age in Emx$B D N F^{K O}$ mice $(p<0.001)$, and again between 3 and 5 weeks $(p<0.05)$ in these animals. Thus, BDNF is not required for layer II/III pyramidal neuron somas to grow to their full size, but is necessary for the maintenance of soma size between 14 and $35 \mathrm{~d}$ of age.

Next, we analyzed the number of primary dendrites, which increases rapidly during the first two postnatal weeks in rats to beyond the adult level before declining slightly (Miller, 1988). At 5 weeks, the number of primary dendrites was reduced, by $36 \%$ $(p<0.001)$ compared with wild-type mice and 25\% $(p<0.001)$ compared with heterozygotes (Fig. 5D-I, K). To distinguish between possible BDNF requirements for the development or maintenance of dendrite number, we analyzed younger animals. At 2 weeks of age there was no difference between the genotypes (Fig. $5 A-C, K$ ), but at 3 weeks the number of primary dendrites was reduced by $19 \%(p<0.05)$ compared with wild-type. Importantly, the number of primary dendrites in $E m x-B D N F^{K O}$ mice was significantly reduced between 2 weeks of age and both 3 and 5 weeks of age $(p<0.01)$, indicating that some primary dendrites formed in $E m x-B D N F^{K O}$ mice but were subsequently lost, as opposed to a lack of dendrite growth per se. Thus, BDNF is required in a similar time frame beginning after 2 weeks of age for maintenance of both soma size and primary basal dendrite number in layer II/III of the visual cortex.

Several reports have described BDNF influences on the branching of cortical dendrites. Thus, we analyzed basal dendrite branching in layer II/III. At 2 weeks of age there was no difference in the number of branch points per primary dendrite between the genotypes, but by 5 weeks of age there was a $29 \%$ reduction compared with wild-type and a $34 \%$ reduction compared with heterozygotes $(p<0.05)$ (Fig. $5 L)$. Analysis of branch points per dendrite order revealed significant differences between genotypes (main effect for genotype $F_{(2,9)}=29.03, p<0.0001$ ) (Fig. 5i), with intermediate to distal dendrites most affected. Modified Sholl analysis revealed a decrease in basal dendritic arbor complexity at $40 \mu \mathrm{m}$ and greater distances from the neuron soma (Fig. 5O) $(p<0.001)$, also indicating that distal dendritic branching is more severely affected than proximal branching. In combination, these data revealed that cortical BDNF is not required for the initial elaboration of layer II/III neuron basal dendrites, but is required for the maintenance of the dendritic tree.

As described above, we did not detect cortical BDNF requirements for the survival or biochemical differentiation of specific excitatory and inhibitory neurons, but found that cortical BDNF is required for the maintenance of the size of layer II/III excitatory neurons. We were curious whether there might be a similar requirement of BDNF for maintenance of interneuron size. We measured the soma area of cortical inhibitory neurons and found that at 3 weeks of age the soma area of calbindin-positive neurons from layers IV-VI was reduced by $20 \%(p<0.001)$ compared with both wild-type and heterozygous littermates (Fig. 5i). The soma of parvalbumin-positive neurons was reduced by $\sim 10 \%$ $(p<0.01)$ (Fig. 5P). Thus, in addition to excitatory neurons, some inhibitory neurons require cortically produced BDNF for normal morphology by 3 weeks of age. Importantly, the timing of these BDNF requirements correlates well with the timing of the onset of substantial BDNF expression in visual cortex as determined using the lac $Z$ marker present in $B D N F^{\text {lac } Z /+}$ mice (Fig. $5 P-R)$.

\section{Discussion}

Lack of a detected requirement for neuronal survival

Several reports have indicated that $\mathrm{BDNF} / \mathrm{TrkB}$ signaling supports the survival of cortical neurons in vitro and in vivo (Ghosh 

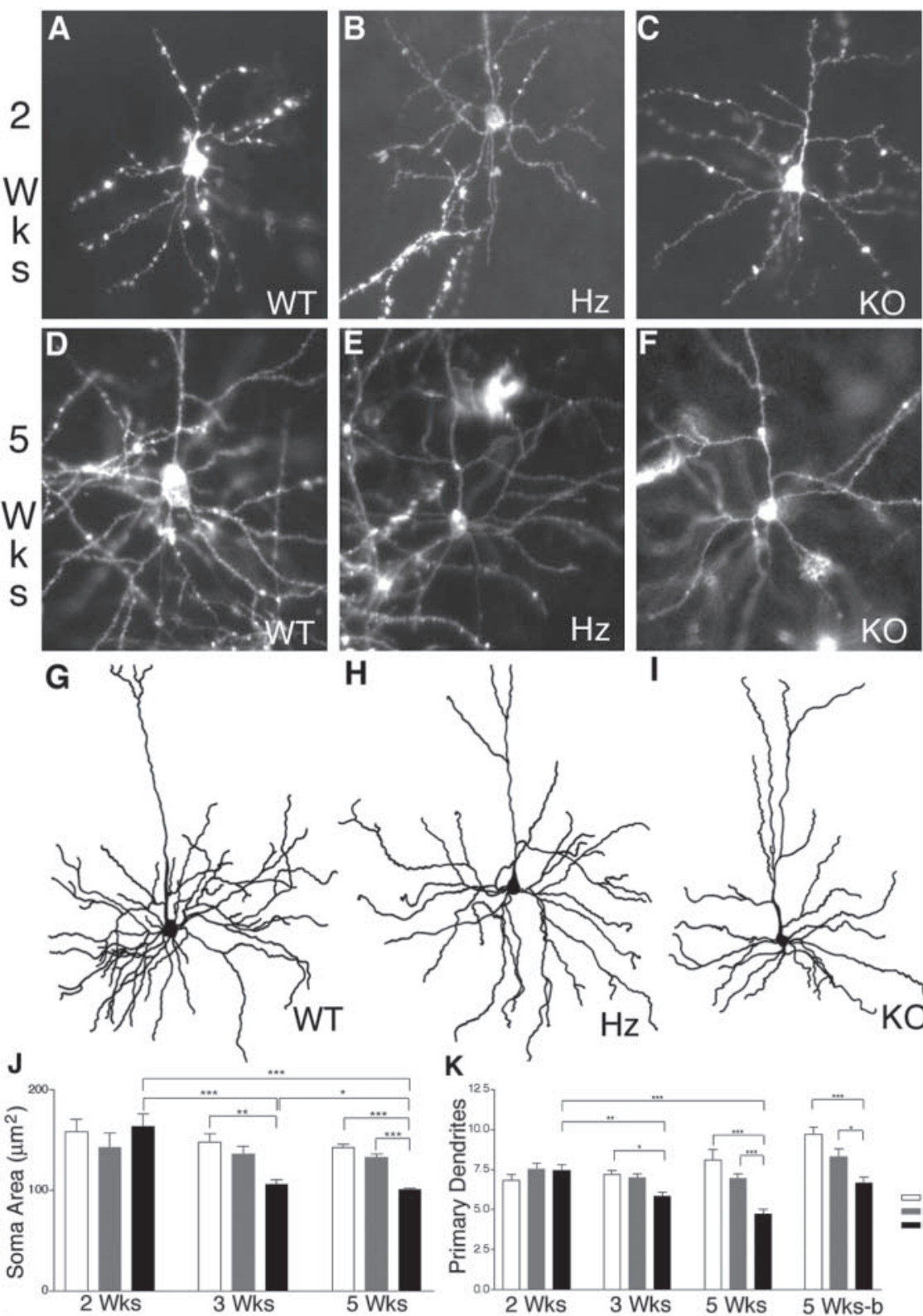

H
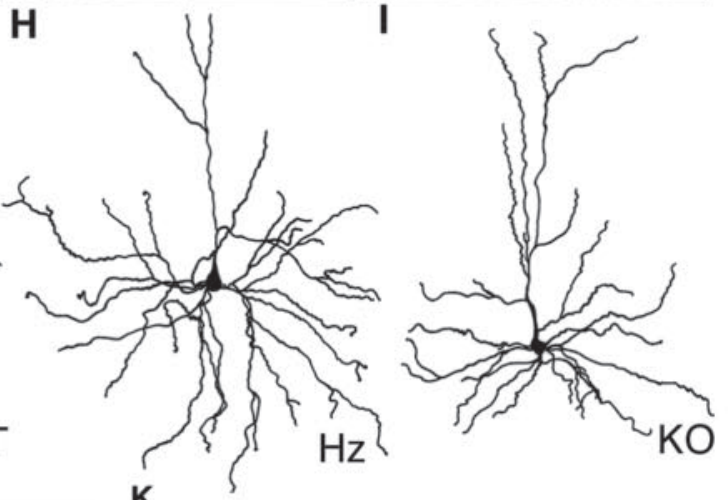

K
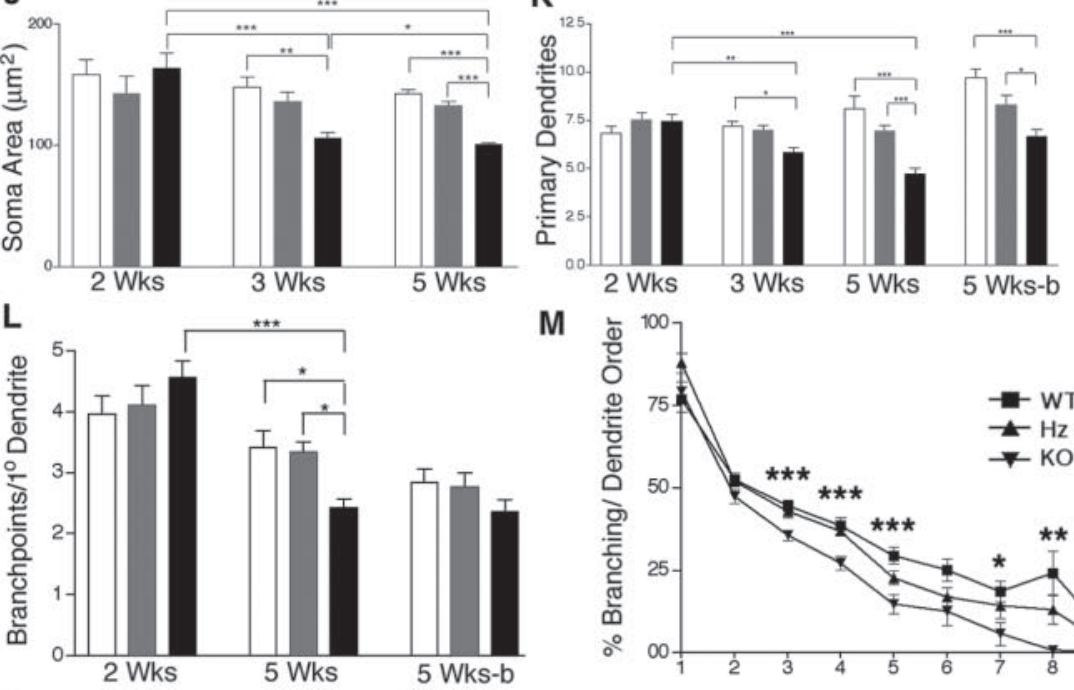

M
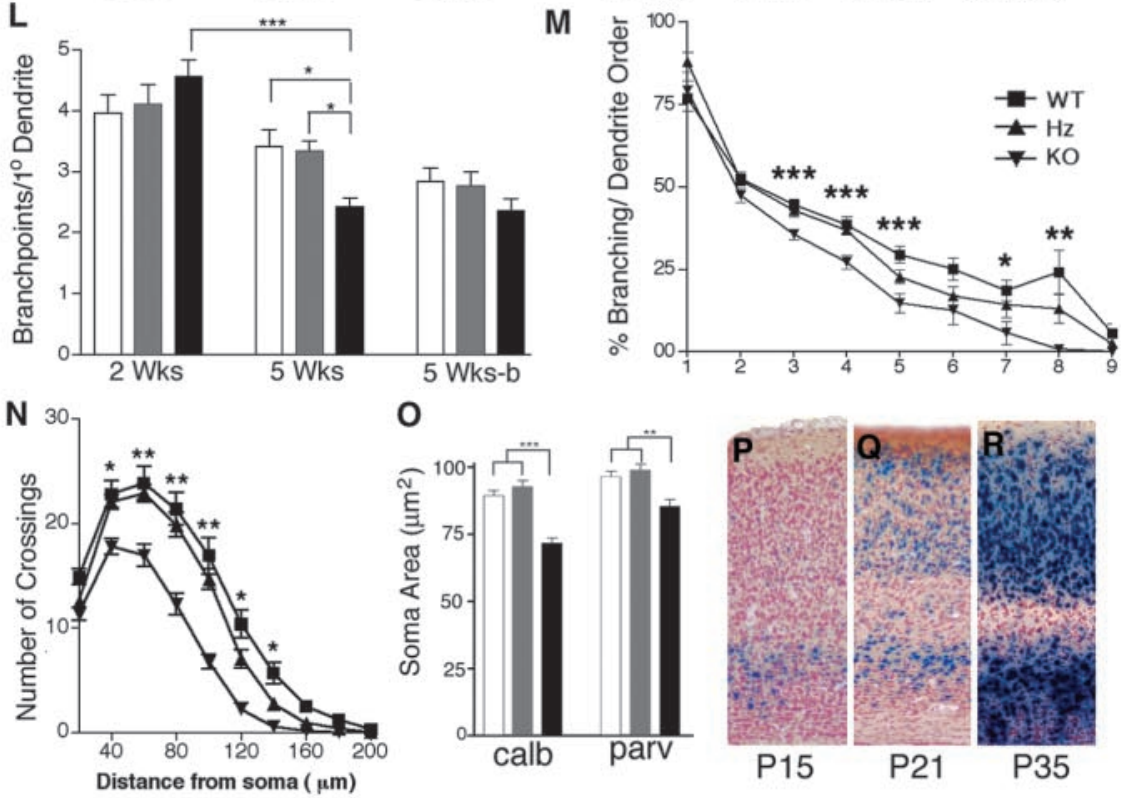

0
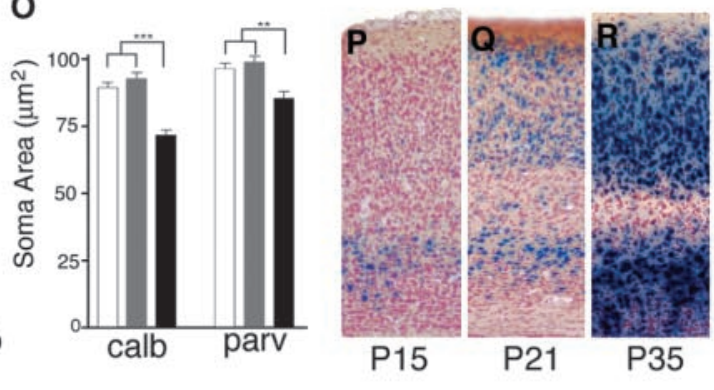

et al., 1994; Alcantara et al., 1997; Ohgoh et al., 1998; Araki et al., 2000; Xu et al., 2000; Catapano et al., 2001). Our counts of specific neuronal subpopulations and ratios of neurons to non-neuronal cells revealed no effect of a loss of cortical BDNF. This result is notably distinct from the analysis of late-onset forebrain-restricted $\operatorname{TrkB}$ mutant mice, with reported losses of ER81- and SCIP-expressing cortical neurons (Xu et al., 2000). The loss of TrkB is expected to lead to a more severe phenotype than the loss of BDNF, because in addition to BDNF, both NT-4/5 and NT-3 can activate TrkB (Barbacid, 1994; Patapoutian and Reichardt, 2001). Increased expression of alternate TrkB ligands might compensate for the loss of BDNF. Indeed, we found that NT-3 protein levels were significantly elevated in the cortex and hippocampus of 5-week-old Emx-BDNF ${ }^{K O}$ mice (approximately twofold between $E m x$ $B D N F^{K O}$ mice and $B D N F^{l o x /+}, p<0.05$, $n=3$ mice per genotype), supporting this hypothesis. Also, developmental compensations might occur in Emx-BDNF ${ }^{K O}$ mice that do not occur in the in vitro experiments or after adult-onset deletion of TrkB. Regardless, our data suggest that BDNF is not necessary for the survival of most cortical neurons during the first 5 weeks of life in the mouse.

\section{Interneuron differentiation}

In vitro and in vivo studies have suggested that BDNF may influence the maturation of GABAergic inhibitory interneurons (Marty et al., 1997). P15-P20 BDNF null mutant mice had reduced expression of NPY, parvalbumin, and calbindin in the cortex and hippocampus (Jones et al., 1994), and mice overexpressing BDNF under control of the $\alpha$ CaMKII ( $\alpha$ subunit calcium calmodulin kinase II) promoter had precocious expression of the inhibitory neuron markers glutamic acid decarboxylase (GAD65) and parvalbumin (Huang et al., 1999). Thus, we were surprised that cortical BDNF, although sufficient to enhance differentiated properties of inhibitory neurons, was not necessary for their biochemical maturation, as assayed using immunocytochemistry for GABA, parvalbumin, and calbindin. Perhaps subcortical afferents still expressing BDNF in $E m x-B D N F^{K O}$ mice including cholinergic afferents from the basal forebrain (Beaulieu and Somogyi, 1991), dopaminergic afferents from the midbrain (Sesack et al., 1995), or noradrenergic afferents from the brainstem (Paspalas and Papadopoulos, 1999) provide a source for the differentiation of interneurons. 
BDNF is required for maintenance of neuronal morphology Our results support the hypothesis that BDNF expression in the developing forebrain is necessary for the maintenance of the anatomical characteristics of cortical neurons, both soma size and dendritic structure. Neuronal soma size has been correlated with both advancing neuronal development and increased neural activity. The molecular regulation of soma size is not well understood. Signaling through Ras G-protein and Akt protein kinase has been shown to affect cell size in multiple organisms and cell types, including murine cortical neurons (Heumann et al., 2000; Kozma and Thomas, 2002) and Ras and Akt are regulated by TrkB signaling (Miller and Kaplan, 2001), suggesting that reduced signaling through Ras and Akt could lead to neuronal soma shrinkage in the absence of BDNF.

The processes of initial dendrite formation and branching occurred normally in the absence of cortical BDNF through the first two postnatal weeks. Thus, any influence of the low levels of BDNF present in the visual cortex before 2 weeks of age on layer II/III pyramidal neuron development is limited. However, when BDNF expression normally rises dramatically in the cortex between 2 and 3 weeks of age (Timmusk et al., 1994) (Fig. 5L), a requirement for the sustenance of neuronal size and dendritic complexity became apparent. By 3 and 5 weeks of age, Emx$B D N F^{K O}$ mice exhibited significant reductions of basal dendritic complexity in layer II/III pyramidal neurons.

Similarly, in another in vivo study, Xu et al. (2000) reported that the loss of TrkB sometime between 2 and 4 weeks of age leads to reduced layer II/III cortical neuron soma size and basal dendrite complexity at 6 weeks of age, indicating an ongoing need for TrkB signaling in the maintenance of these cells. It is important to note that the timing of mutation is different in our study and that of Xu et al. (2000). In their mice, there is little loss of $\operatorname{TrkB}$ at 2 weeks, but it plateaus at $\sim 4$ weeks of age (Xu et al., 2000). In contrast, Emx-BDNF ${ }^{K O}$ mice undergo deletion of the BDNF coding exon in the embryo. It is possible that the similarities in the loss of cortical neuron dendritic arborization between 2 and 3 weeks in $E m x-B D N F^{K O}$ mice and 4 and 6 weeks in late-onset $\operatorname{TrkB}$ mutants (Xu et al., 2000) indicate that developmental and adult functions of BDNF in the cortex are essentially identical.

Previous studies of the effects of added BDNF on dendrites in cultured cortical slices have been interpreted mostly in the context of roles for BDNF-TrkB signaling in initiating dendrite growth (McAllister et al., 1995, 1996, 1997; Horch et al., 1999; Niblock et al., 2000; Yacoubian and Lo, 2000). However, the ability of TrkB-IgG to cause the loss of previously existing dendrites in layer IV has been reported previously (McAllister et al., 1997), consistent with our finding that BDNF is necessary for dendrite maintenance in layer II/III in vivo.

$\leftarrow$

Figure 5. BDNF is required for the maintenance of layer II/III pyramidal neuron morphology. Examples of Dil labeled visual cortical layer II/III pyramidal neurons from 2-week-old ( $A-C$ and 5-week-old ( $D-F)$ mice and biocytin-filled and camera lucidareconstructed layer II/III visual cortical pyramidal neurons from 5 -week-old mice ( $G-I)$.J, Soma area of layer II/III neurons at 2,3, and 5 weeks of age ( $n=3$ mice per genotype, 15 cells per mouse). $K$, Number of primary dendrites from 2-, 3-, and 5 -week-old mice. ${ }^{*} p<0.05 ;{ }^{* *} p<0.01 ; n=3$ mice per genotype, 15 cells per mouse. L, Number of branch points per primary dendrites for 2 - and 5 -week-old mice ( $n=3$ mice per genotype, 15 cells per mouse). $M$, Number of branches per dendrite order for 2 - and 5-week-old mice. ${ }^{*} p<0.05 ;{ }^{* *} p<0.01 ; n=3$ mice per genotype, 15 cells per mouse. H, Modified Sholl analysis of layer II/III pyramidal neurons from 5 -week-old mice. ${ }^{*} p<0.05 ;{ }^{* *} p<0.01 ; n=3$ mice per genotype, 7 cells per mouse. Data in $J-L$ were obtained from neurons visualized through diolistic labeling, with the exception that biocytin-filled and camera lucida-reconstructed neurons were used for some of the 5-week-old animals for comparison (-b). Data in $M$ and $N$ were obtained from biocytin-filled and camera lucida-reconstructed neurons. 0, Soma areas measured from calbindin (calb) and parvalbumin (parv)positive cortical neurons from 3-week-old mice revealed a significant difference between $\mathrm{Emx}^{-B D N F}{ }^{\mathrm{KO}}$ and control genotypes. ${ }^{* *} p<0.01 ;{ }^{* *} p<0.01 ; n=3$ mice per genotype, $55-75$ cells per mouse. $P-R$, BDNF expression during postnatal cortical development as detected by $X$-gal staining of $40 \mu \mathrm{m}$ sections from BDNF lacz/+ mice. Postnatal ages are indicated at the bottom.
Although some of the specific anatomical abnormalities in layer II/III of $E m x-B D N F^{K O}$ mice are similar to predictions from BDNF effects on cultured cortical slices, others are different. Simr to our findings, Niblock et al. (2000) found that bath applipyramidal neurons. In contrast to our finding they found effect on soma size or the number of basal dendrites. Horch et al. (1999) found that overexpression of BDNF in ferret slices led to an increase in the number of layer II/III basal dendrites, consistent with our observations of a loss of basal dendrites in the absence of BDNF. In contrast to our findings, they found reduced distal arborization and no effect of TrkB-IgG on the number of asal dendrites. The differences between the results of these in studies and our analysis of the BDNF mutants are likely to environment and more intact neural circuitry in vivo relative to cured slice preparations. signaling could regulate the activity of members of the Rho fam of GTPases, known to modify dendrite number, form, and stability in a variety of neural types including cortical neurons (19ill et al., 1997; Li et al., 2000; Nakayama et al., 2000; (20) signaling through the TrkA receptor is regulated by interactions between Rho and Rac (Yamaguchi et al., 2001; Nusser et al., 2002). Given that NGF-TrkA and BDNF-TrkB signaling share late dendrite structure and stability in part through the Rho fam-

Alternatively, BDNF could influence dendritic structure indirectly through modulating synaptic activity. The levels and/or patterns of neuronal activity could be perturbed in the absence of BDNF. Both the development and the stability of dendritic form is sensitive to neural activity and is influenced by the process of synaptogenesis (Cline, 2001; Wong and Ghosh, 2002). BDNF can 1998; Rutherford et al., 1998; Desai et al., 1999; Kinoshita et al., for maximal long-term potentiation of synaptic strength (Poo, 2001) could suggest a requirement for stabilization of many synapses present in wild-type animals.

Regardless of whether BDNF directly or indirectly influences dendrite structure, our results indicate that the essential function for cortical BDNF is not to support neuronal survival, the classic neurotrophic function, or to regulate the initial growth of cortical dendritic trees, as suggested by in vitro studies. Instead, cortical BDNF appears to support the "survival" of dendritic structure that is generated through BDNFindependent mechanisms. This requirement for dendrite maintenance occurs during the period of life when BDNF expression normally rises (between eye opening and weaning in murine visual 
cortex). This is particularly intriguing considered in the context of models of activity-dependent development of circuitry. In such models, an initially exuberant and relatively nonspecific set of connections is formed and then subsequently refined through a process in which connections are selected based upon Hebbian rules (Katz and Shatz, 1996). A lack of BDNF could interfere with the maintenance of many connections by not allowing their reinforcement. It is apparent from our work that BDNF signaling is necessary in vivo for the maintenance of cortical neuron morphology during a key phase of life, during which there is activitydependent reorganization of cortical circuitry (Gordon and Stryker, 1996). Elucidation of the molecular mechanisms underlying these actions of BDNF on cortical dendrites and synapses will likely be fruitful in furthering our understanding of cortical plasticity.

\section{References}

Akaneya Y, Tsumoto T, Hatanaka H (1996) Brain-derived neurotrophic factor blocks long-term depression in rat visual cortex. J Neurophysiol 76:4198-4201.

Akaneya Y, Tsumoto T, Kinoshita S, Hatanaka H (1997) Brain-derived neurotrophic factor enhances long-term potentiation in rat visual cortex. J Neurosci 17:6707-6716.

Alcantara S, Frisen J, del Rio JA, Soriano E, Barbacid M, Silos-Santiago I (1997) TrkB signaling is required for postnatal survival of CNS neurons and protects hippocampal and motor neurons from axotomy-induced cell death. J Neurosci 17:3623-3633.

Antonini A, Fagiolini M, Stryker MP (1999) Anatomical correlates of functional plasticity in mouse visual cortex. J Neurosci 19:4388-4406.

Araki T, Yamada M, Ohnishi H, Sano SI, Hatanaka H (2000) BIT/SHPS-1 enhances brain-derived neurotrophic factor-promoted neuronal survival in cultured cerebral cortical neurons. J Neurochem 75:1502-1510.

Barbacid M (1994) The Trk family of neurotrophin receptors. J Neurobiol 25:1386-1403.

Beaulieu C, Somogyi P (1991) Enrichment of cholinergic synaptic terminals on GABAergic neurons and coexistence of immunoreactive GABA and choline acetyltransferase in the same synaptic terminals in the striate cortex of the cat. J Comp Neurol 304:666-680.

Bibel M, Barde YA (2000) Neurotrophins: key regulators of cell fate and cell shape in the vertebrate nervous system. Genes Dev 14:2919-2937.

Catapano LA, Arnold MW, Perez FA, Macklis JD (2001) Specific neurotrophic factors support the survival of cortical projection neurons at distinct stages of development. J Neurosci 21:8863-8872.

Cline HT (2001) Dendritic arbor development and synaptogenesis. Curr Opin Neurobiol 11:118-126.

Desai NS, Rutherford LC, Turrigiano GG (1999) BDNF regulates the intrinsic excitability of cortical neurons. Learn Mem 6:284-291.

Doetschman TC, Eistetter H, Katz M, Schmidt W, Kemler R (1985) The in vitro development of blastocyst-derived embryonic stem cell lines: formation of visceral yolk sac, blood islands and myocardium. J Embryol Exp Morphol 87:27-45.

Dymecki SM (1996) Flp recombinase promotes site-specific DNA recombination in embryonic stem cells and transgenic mice. Proc Natl Acad Sci USA 93:6191-6196.

Ernfors P, Lee KF, Jaenisch R (1994) Mice lacking brain-derived neurotrophic factor develop with sensory deficits. Nature 368:147-150.

Finkbeiner S (2000) Calcium regulation of the brain-derived neurotrophic factor gene. Cell Mol Life Sci 57:394-401.

Franklin KBJ, Paxinos G (1997) The mouse brain in stereotaxic coordinates. San Diego, CA: Academic Press.

Frisen J, Verge VM, Fried K, Risling M, Persson H, Trotter J, Hokfelt T, Lindholm D (1993) Characterization of glial trkB receptors: differential response to injury in the central and peripheral nervous systems. Proc Natl Acad Sci USA 90:4971-4975.

Gan WB, Grutzendler J, Wong WT, Wong RO, Lichtman JW (2000) "DiOlistic" labeling of the nervous system using lipophilic dye combinations. Neuron 27:219-225.

Gates MA, Tai CC, Macklis JD (2000) Neocortical neurons lacking the protein-tyrosine kinase $\mathrm{B}$ receptor display abnormal differentiation and process elongation in vitro and in vivo. Neuroscience 98:437-447.
Ghosh A, Carnahan J, Greenberg ME (1994) Requirement for BDNF in activity-dependent survival of cortical neurons. Science 263:1618-1623.

Gordon JA, Stryker MP (1996) Experience-dependent plasticity of binocular responses in the primary visual cortex of the mouse. J Neurosci 16:3274-3286.

Gorski JA, Talley T, Qiu M, Puelles L, Rubenstein JL, Jones KR (2002) Cortical excitatory neurons and glia, but not GABAergic neurons, are produced in the Emx1-expressing lineage. J Neurosci 22:6309-6314.

Gorski JA, Balogh SA, Wehner JM, Jones KR (2003) Learning deficits in forebrain-restricted BDNF mutant mice. Neuroscience (in press).

Hayashi K, Ohshima T, Mikoshiba K (2002) Pak1 is involved in dendrite initiation as a downstream effector of Rac1 in cortical neurons. Mol Cell Neurosci 20:579-594.

Heumann R, Goemans C, Bartsch D, Lingenhohl K, Waldmeier PC, Hengerer B, Allegrini PR, Schellander K, Wagner EF, Arendt T, Kamdem RH, ObstPernberg K, Narz F, Wahle P, Berns H (2000) Transgenic activation of Ras in neurons promotes hypertrophy and protects from lesion-induced degeneration. J Cell Biol 151:1537-1548.

Hohn A, Leibrock J, Bailey K, Barde YA (1990) Identification and characterization of a novel member of the nerve growth factor/brain-derived neurotrophic factor family. Nature 344:339-341.

Horch HW, Kruttgen A, Portbury SD, Katz LC (1999) Destabilization of cortical dendrites and spines by BDNF. Neuron 23:353-364.

Huang EJ, Reichardt LF (2001) Neurotrophins: roles in neuronal development and function. Annu Rev Neurosci 24:677-736.

Huang ZJ, Kirkwood A, Pizzorusso T, Porciatti V, Morales B, Bear MF, Maffei L, Tonegawa S (1999) BDNF regulates the maturation of inhibition and the critical period of plasticity in mouse visual cortex. Cell 98:739-755.

Huber KM, Sawtell NB, Bear MF (1998) Brain-derived neurotrophic factor alters the synaptic modification threshold in visual cortex. Neuropharmacology 37:571-579.

Itami C, Mizuno K, Kohno T, Nakamura S (2000) Brain-derived neurotrophic factor requirement for activity-dependent maturation of glutamatergic synapse in developing mouse somatosensory cortex. Brain Res 857:141-150.

Jones KR, Farinas I, Backus C, Reichardt LF (1994) Targeted disruption of the BDNF gene perturbs brain and sensory neuron development but not motor neuron development. Cell 76:989-999.

Kafitz KW, Rose CR, Thoenen H, Konnerth A (1999) Neurotrophin-evoked rapid excitation through TrkB receptors. Nature 401:918-921.

Katz LC, Shatz CJ (1996) Synaptic activity and the construction of cortical circuits. Science 274:1133-1138.

Kernie SG, Liebl DJ, Parada LF (2000) BDNF regulates eating behavior and locomotor activity in mice. EMBO J 19:1290-1300.

Kinoshita S, Yasuda H, Taniguchi N, Katoh-Semba R, Hatanaka H, Tsumoto $\mathrm{T}$ (1999) Brain-derived neurotrophic factor prevents low-frequency inputs from inducing long-term depression in the developing visual cortex. J Neurosci 19:2122-2130.

Klein R, Smeyne RJ, Wurst W, Long LK, Auerbach BA, Joyner AL, Barbacid M (1993) Targeted disruption of the trkB neurotrophin receptor gene results in nervous system lesions and neonatal death. Cell 75:113-122.

Kozma SC, Thomas G (2002) Regulation of cell size in growth, development and human disease: PI3K, PKB and S6K. Bioessays 24:65-71.

Laird PW, Zijderveld A, Linders K, Rudnicki MA, Jaenisch R, Berns A (1991) Simplified mammalian DNA isolation procedure. Nucleic Acids Res 19:4293.

Leslie KR, Nelson SB, Turrigiano GG (2001) Postsynaptic depolarization scales quantal amplitude in cortical pyramidal neurons. J Neurosci 21:RC170.

Li Z, Van Aelst L, Cline HT (2000) Rho GTPases regulate distinct aspects of dendritic arbor growth in Xenopus central neurons in vivo. Nat Neurosci 3:217-225.

Lin JH, Saito T, Anderson DJ, Lance-Jones C, Jessell TM, Arber S (1998) Functionally related motor neuron pool and muscle sensory afferent subtypes defined by coordinate ETS gene expression. Cell 95:393-407.

Luo L (2002) Actin cytoskeleton regulation in neuronal morphogenesis and structural plasticity. Annu Rev Cell Dev Biol 18:601-635.

Lyons WE, Mamounas LA, Ricaurte GA, Coppola V, Reid SW, Bora SH, Wihler C, Koliatsos VE, Tessarollo L (1999) Brain-derived neurotrophic factor-deficient mice develop aggressiveness and hyperphagia in conjunction with brain serotonergic abnormalities. Proc Natl Acad Sci USA 96:15239-15244. 
Maisonpierre PC, Belluscio L, Friedman B, Alderson RF, Wiegand SJ, Furth ME, Lindsay RM, Yancopoulos GD (1990) NT-3, BDNF, and NGF in the developing rat nervous system: parallel as well as reciprocal patterns of expression. Neuron 5:501-509.

Marty S, Berzaghi MdaP, Berninger B (1997) Neurotrophins and activitydependent plasticity of cortical interneurons. Trends Neurosci 20:198-202.

Maxwell IH, Harrison GS, Wood WM, Maxwell F (1989) A DNA cassette containing a trimerized SV40 polyadenylation signal which efficiently blocks spurious plasmid-initiated transcription. Biotechniques 7:276-280.

McAllister AK, Lo DC, Katz LC (1995) Neurotrophins regulate dendritic growth in developing visual cortex. Neuron 15:791-803.

McAllister AK, Katz LC, Lo DC (1996) Neurotrophin regulation of cortical dendritic growth requires activity. Neuron 17:1057-1064.

McAllister AK, Katz LC, Lo DC (1997) Opposing roles for endogenous BDNF and NT-3 in regulating cortical dendritic growth. Neuron 18:767-778.

McKeon RJ, Silver J, Large TH (1997) Expression of full-length trkB receptors by reactive astrocytes after chronic CNS injury. Exp Neurol 148:558-567.

Miller FD, Kaplan DR (2001) Neurotrophin signalling pathways regulating neuronal apoptosis. Cell Mol Life Sci 58:1045-1053.

Miller M (1988) Development of projection and local circuit neurons in neocortex. In: Cerebral cortex (Peters A, Jones EG, eds), pp 133-175. New York: Plenum.

Minichiello L, Korte M, Wolfer D, Kuhn R, Unsicker K, Cestari V, RossiArnaud C, Lipp HP, Bonhoeffer T, Klein R (1999) Essential role for TrkB receptors in hippocampus-mediated learning. Neuron 24:401-414.

Monuki ES, Weinmaster G, Kuhn R, Lemke G (1989) SCIP: a glial POU domain gene regulated by cyclic AMP. Neuron 3:783-793.

Nakayama AY, Harms MB, Luo L (2000) Small GTPases Rac and Rho in the maintenance of dendritic spines and branches in hippocampal pyramidal neurons. J Neurosci 20:5329-5338.

Niblock MM, Brunso-Bechtold JK, Riddle DR (2000) Insulin-like growth factor I stimulates dendritic growth in primary somatosensory cortex. J Neurosci 20:4165-4176.

Nusser N, Gosmanova E, Zheng Y, Tigyi G (2002) Nerve growth factor signals through TrkA, phosphatidylinositol 3-kinase, and Racl to inactivate RhoA during the initiation of neuronal differentiation of PC12 cells. J Biol Chem 277:35840-35846.

Ohgoh M, Kimura M, Ogura H, Katayama K, Nishizawa Y (1998) Apoptotic cell death of cultured cerebral cortical neurons induced by withdrawal of astroglial trophic support. Exp Neurol 149:51-63.

Paspalas CD, Papadopoulos GC (1999) Noradrenergic innervation of peptidergic interneurons in the rat visual cortex. Cereb Cortex 9:844-853.

Patapoutian A, Reichardt LF (2001) Trk receptors: mediators of neurotrophin action. Curr Opin Neurobiol 11:272-280.

Polleux F, Whitford KL, Dijkhuizen PA, Vitalis T, Ghosh A (2002) Control of cortical interneuron migration by neurotrophins and PI3-kinase signaling. Development 129:3147-3160.
Poo MM (2001) Neurotrophins as synaptic modulators. Nat Rev Neurosci 2:24-32.

Roback JD, Marsh HN, Downen M, Palfrey HC, Wainer BH (1995) BDNFactivated signal transduction in rat cortical glial cells. Eur J Neurosci 7:849-862.

Rutherford LC, Nelson SB, Turrigiano GG (1998) BDNF has opposite effects on the quantal amplitude of pyramidal neuron and interneuron excitatory synapses. Neuron 21:521-530.

Sesack SR, Snyder CL, Lewis DA (1995) Axon terminals immunolabeled for dopamine or tyrosine hydroxylase synapse on GABA-immunoreactive dendrites in rat and monkey cortex. J Comp Neurol 363:264-280.

Sholl DA (1953) Dendritic organization in the neurons of the visual and motor cortices of the cat. J Anat 87:387-406.

Silos-Santiago I, Fagan AM, Garber M, Fritzsch B, Barbacid M (1997) Severe sensory deficits but normal CNS development in newborn mice lacking TrkB and TrkC tyrosine protein kinase receptors. Eur J Neurosci 9:2045-2056.

Takei N, Sasaoka K, Inoue K, Takahashi M, Endo Y, Hatanaka H (1997) Brain-derived neurotrophic factor increases the stimulation-evoked release of glutamate and the levels of exocytosis-associated proteins in cultured cortical neurons from embryonic rats. J Neurochem 68:370-375.

Tashiro A, Minden A, Yuste R (2000) Regulation of dendritic spine morphology by the rho family of small GTPases: antagonistic roles of Rac and Rho. Cereb Cortex 10:927-938.

Threadgill R, Bobb K, Ghosh A (1997) Regulation of dendritic growth and remodeling by Rho, Rac, and Cdc42. Neuron 19:625-634.

Timmusk T, Palm K, Metsis M, Reintam T, Paalme V, Saarma M, Persson H (1993) Multiple promoters direct tissue-specific expression of the rat BDNF gene. Neuron 10:475-489.

Timmusk T, Belluardo N, Persson H, Metsis M (1994) Developmental regulation of brain-derived neurotrophic factor messenger RNAs transcribed from different promoters in the rat brain. Neuroscience 60:287-291.

Webster MJ, Weickert CS, Herman MM, Kleinman JE (2002) BDNF mRNA expression during postnatal development, maturation and aging of the human prefrontal cortex. Brain Res Dev Brain Res 139:139-150.

Wong RO, Ghosh A (2002) Activity-dependent regulation of dendritic growth and patterning. Nat Rev Neurosci 3:803-812.

Wong WT, Faulkner-Jones BE, Sanes JR, Wong RO (2000) Rapid dendritic remodeling in the developing retina: dependence on neurotransmission and reciprocal regulation by Rac and Rho. J Neurosci 20:5024-5036.

Xu B, Zang K, Ruff NL, Zhang YA, McConnell SK, Stryker MP, Reichardt LF (2000) Cortical degeneration in the absence of neurotrophin signaling: dendritic retraction and neuronal loss after removal of the receptor TrkB. Neuron 26:233-245.

Yacoubian TA, Lo DC (2000) Truncated and full-length TrkB receptors regulate distinct modes of dendritic growth. Nat Neurosci 3:342-349.

Yamaguchi Y, Katoh H, Yasui H, Mori K, Negishi M (2001) RhoA inhibits the nerve growth factor-induced Racl activation through Rho-associated kinase-dependent pathway. J Biol Chem 276:18977-18983. 